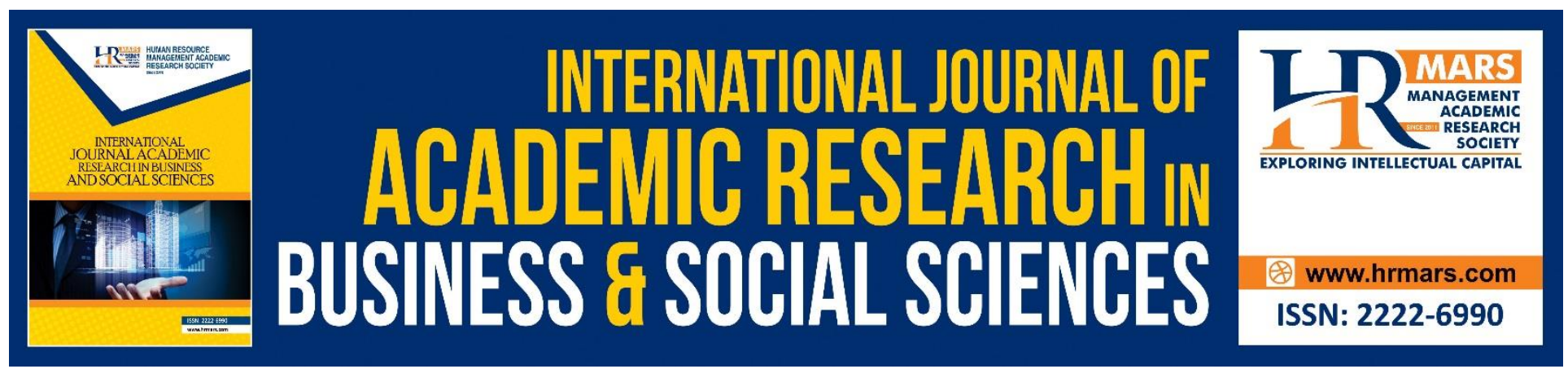

\title{
Voice Changer App in Enhancing Social Expressions Skills Among Pupils
}

Francesca Santa binti Dedo, Aenrietta Alla anak Eddie, Treshie Punga anak Sabang, Melor Md Yunus

To Link this Article: http://dx.doi.org/10.6007/IJARBSS/v9-i1/5403

DOI: $\quad 10.6007 /$ IJARBSS/v9-i1/5403

Received: 27 Dec 2018, Revised: 18 Jan 2019, Accepted: 06 Feb 2019

Published Online: 08 Feb 2019

In-Text Citation: (Dedo, Eddie, Sabang, \& Yunus, 2019)

To Cite this Article: Dedo, F. S. binti, Eddie, A. A. anak, Sabang, T. P. anak, \& Yunus, M. M. (2019). Voice Changer App in Enhancing Social Expressions Skills Among Pupils. International Journal of Academic Research in Business and Social Sciences, 9(1), 357-365.

\section{Copyright: (c) 2019 The Author(s)}

Published by Human Resource Management Academic Research Society (www.hrmars.com)

This article is published under the Creative Commons Attribution (CC BY 4.0) license. Anyone may reproduce, distribute, translate and create derivative works of this article (for both commercial and non-commercial purposes), subject to full attribution to the original publication and authors. The full terms of this license may be seen

at: http://creativecommons.org/licences/by/4.0/legalcode

\section{Vol. 9, No. 1, 2019, Pg. 357 - 365}

Full Terms \& Conditions of access and use can be found at http://hrmars.com/index.php/pages/detail/publication-ethics 


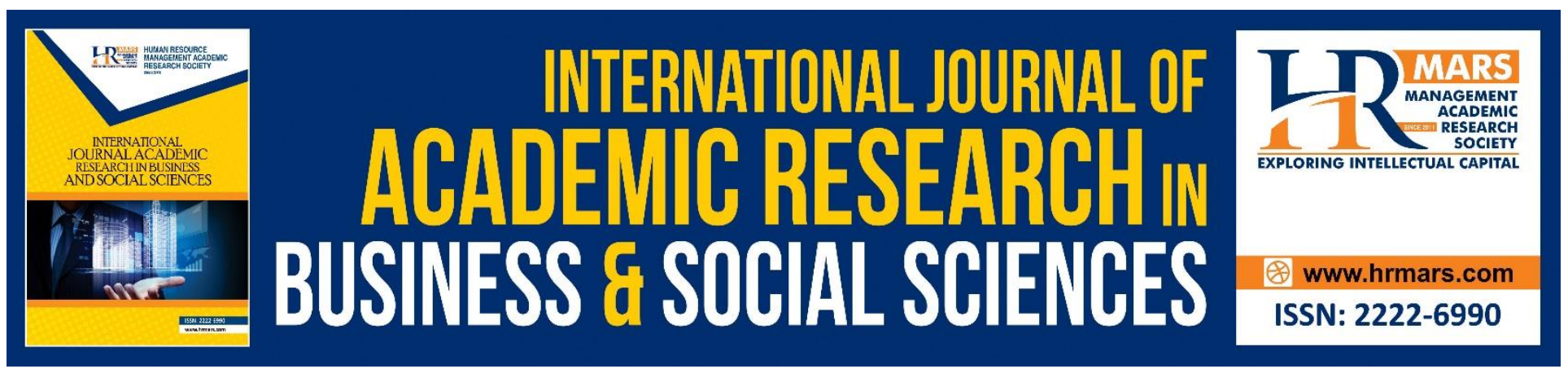

\title{
Voice Changer App in Enhancing Social Expressions Skills Among Pupils
}

\author{
Francesca Santa binti Dedo ${ }^{1,4}$, Aenrietta Alla anak Eddie ${ }^{2,4}$, Treshie \\ Punga anak Sabang ${ }^{3,4}$, Melor Md Yunus ${ }^{4}$ \\ ${ }^{1}$ SK Sungai Penipah, D/A PPD Mukah, 96400 Mukah, Sarawak \\ ${ }^{2}$ SK Selepong, D/A PPD Sri Aman, 95000 Sri Aman, Sarawak \\ ${ }^{3}$ SK Methodist Kapit, D/A PPD Kapit, 96807 Kapit, Sarawak \\ ${ }^{4}$ Faculty of Education, Universiti Kebangsaan Malaysia (UKM), 43600 Bangi, Selangor, Malaysia
}

\begin{abstract}
Throughout the world, children are having difficulty in listening effectively and expressing thought through the verbal responses in an appropriate and polite way. These problems can also be observed among the ESL learners in Malaysian primary schools particularly in Sarawak. Social expression is one of the elements in an effective communication. However, some students struggled to respond and expressing their thoughts politely and appropriately due to the insufficient exposure to the English language. This study explored the application of Voice Changer app in teaching social expressions. The Voice Changer is an app that can be downloaded through Google Play Store for free. This action research was carried out with 20 Year 4 pupils from each of the three suburban schools in Sarawak. The data were gathered through pre-test and post-test, observations as well as questionnaire. The findings showed that the students were able to improve their social expressions skills by able to respond politely and appropriately.
\end{abstract}

Keywords: Social Expressions, Voice Changer, Listening, Respond, ESL

\section{Introduction}

For adults and children alike, social expressions have been exposed to them since an early age. It is a skill that is needed for them to maintain healthy and positive interactions with others. They involved interpersonal skills which entail effective communication, empathy, active listening, and cultural competence by showing respect for people (Skinner, Hyde, McPherson, \& Simpson, 2016). According to Vygotsky's (1978) Social Development Theory, the environment in which children grow up will impact how they think and what they think about, thus, their ability to react to social expressions. He also viewed children's interaction with peers as an effective way of developing social skills and strategies (Vygotsky, 1978). The way the children communicate with each other must be monitored as they are still in their imitation stage. In Bandura's (1977) social learning theory, it is mentioned 
INTERNATIONAL JOURNAL OF ACADEMIC RESEARCH IN BUSINESS AND SOCIAL SCIENCES Vol. 9, No. 1, Jan, 2019, E-ISSN: 2222-6990 @ 2019 HRMARS

that young children would mimic the way the people around them communicate and if the consequences are rewarding, they are likely to continue performing the behaviour.

In the current Malaysian classroom setting, the Malaysian Ministry of Education (MoE) has included a section of the social expression topic in the Ujian Penilaian Sekolah Rendah (UPSR) paper. Carrying 6 marks, it is to evaluate pupils' ability to provide suitable or appropriate responses or expressions in different types of situations and for various purposes (Astro Tutor TV, 2015). This could not be taught through reading alone due to the fact that it has to be practiced through peer-interaction and realworld based situations, thus, teachers need to be creative in delivering input during social expressions lessons to expand the pupils' language in social communication.

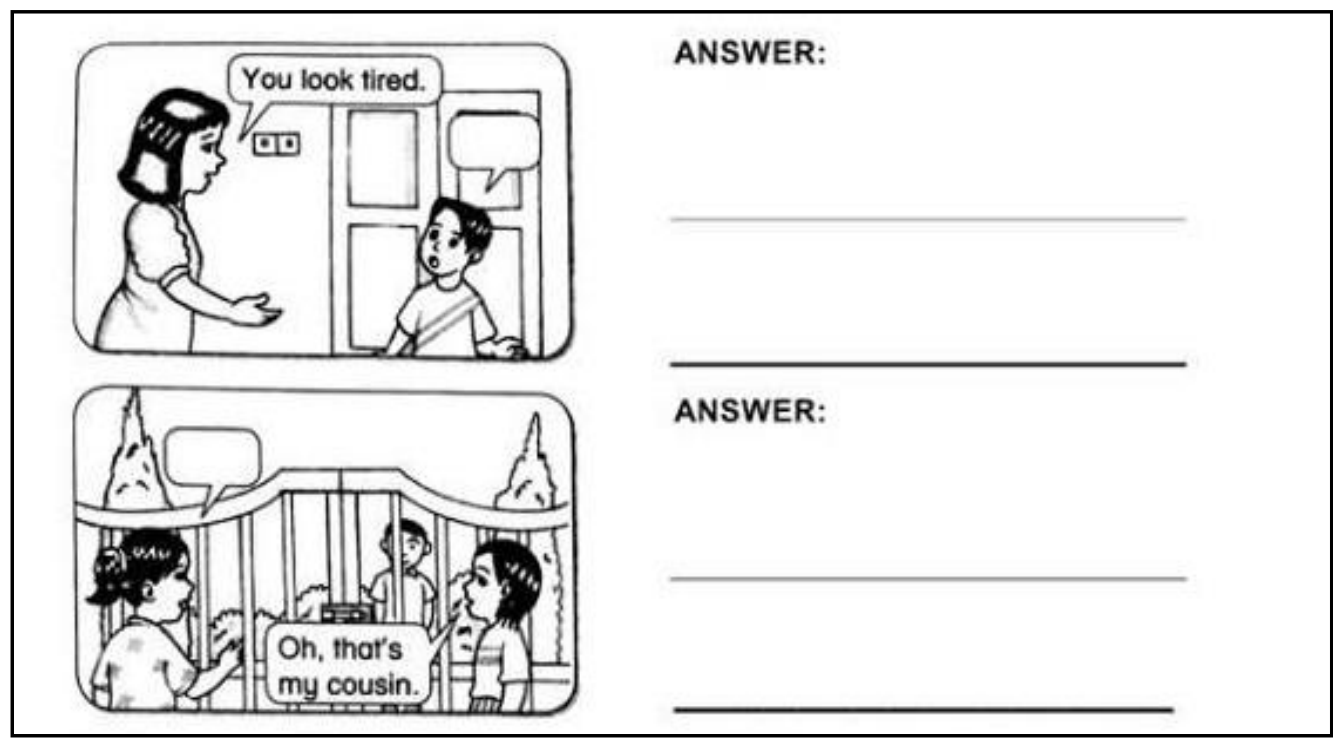

Figure 1: Examples of Social Expressions Questions in the UPSR Paper

Young ESL learners prefer to learn using ICT as it would have made the lesson more enjoyable and meaningful. Employing the Voice Changer app in their lesson is a type of learning strategy that incorporates actions, behaviors, techniques, methods, and operations that are involved in obtaining success to facilitate, regulate, and boost confidence in acquiring the target language (Tigarajan, Yunus \& Azlina, 2016). In addition to that, teaching social expressions by using an app in the smartphone can aid in sharpening the pupils' critical listening skill. Wolvin and Coakley (1994) stated that critical listening makes the listener to evaluate and then accept or reject a message. Through the Voice Changer app, pupils can identify the types of social expressions that they need to respond to in an exciting way, for instance, listening to a birthday party invitation through a robot's voice. The ESL learners can learn listening critically through this technique which allows them to employ their thinking skills and relating them to the message that they received (Muniandy, 2012). It makes them become more attentive and concentrate in the lesson which in turn improves their performance in the social expression language component.

In fact, this way of learning breaks the traditional classroom teaching which is necessary, especially for the pupils in the rural areas as they are less exposed to the latest technological advances and 
gadgets. Because of this, the integration of ICT in the teaching of language skills has been included as one of the main elements in transform shift in the latest Malaysian Education Blueprint (2013-2025). As smartphones and laptops have become more affordable now than the previous years (West, 2013), teachers can effectively implement ICT in the classroom by using an application in their smartphones to teach any language component.

Due to the lack of exposure in the English language being their second or third language, some pupils were struggling to be an effective listener and interacting in an appropriate and correct manner. Considering this issue, this study was aimed to explore the implementation of the Voice Changer app in improving the young pupils' social expression skills.

\section{Literature review}

A study in 2014 conducted by Weger, Bell, Minei and Robinson found that the participants who had received active listening responses were better at social interaction and expression as they felt more understood and acknowledged. Active listening involved reaffirming a paraphrased version of the speaker's message, asking questions when appropriate, and maintaining moderate to high nonverbal conversational involvement (Weger, Bell, Minei \& Robinson, 2014).

Furthermore, in another study by Asemota (2015) concluded that the pupils who were more aware with what was being said to them had sounder judgements about what was heard, thus, they were able to provide the appropriate responses and had better communication skills. Therefore, listening could be seen as a process, which involves more than mere hearing of sounds and noises, but as well as identifying, understanding and interpreting spoken languages (Harrowoth, 1966). The language anxiety experience by the Malaysian learners which hinders them from becoming active learners (Darmi \& Albian, 2013) can be overcame.

\section{Methodology}

An action research design was used for this research based on Chuah Kim Hwa's (2012) adapted action research process from Lewin's 1946 and Laidlaw's 1992 models. This research utilized pre-test and post-test, questionnaire and observations to collect data. The pre-test and post-test were based on the same format in the Section 1(a) in English Paper 1 in UPSR. Meanwhile, the questionnaire was based on the Likert Scale. The participants involved were 20 Year 4 pupils from each of the three selected Primary Schools (Sekolah Kebangsaan) in suburban areas in Sarawak, which summed up to 60 participants in total. In each school, they were divided into three groups; six pupils in Group A, seven pupils in Group B, and seven pupils in Group C. 
INTERNATIONAL JOURNAL OF ACADEMIC RESEARCH IN BUSINESS AND SOCIAL SCIENCES

Vol. 9, No. 1, Jan, 2019, E-ISSN: 2222-6990 @ 2019 HRMARS

\section{Results}

Below are the findings of the research.

\begin{tabular}{|c|c|c|c|c|c|c|c|}
\hline $\begin{array}{c}\text { Scho } \\
\text { ol }\end{array}$ & Participants & $\begin{array}{c}\text { Averag } \\
\text { e Pre } \\
\text { Test } \\
\text { Score }\end{array}$ & $\begin{array}{c}\text { Percentag } \\
\mathbf{e}\end{array}$ & $\begin{array}{c}\text { Average } \\
\text { Post Test } \\
\text { Score }\end{array}$ & $\begin{array}{c}\text { Percentag } \\
\text { e }\end{array}$ & $\begin{array}{c}\text { Average } \\
\text { Score } \\
\text { Incremen } \\
\text { t }\end{array}$ & $\begin{array}{c}\text { Percentage } \\
\text { of } \\
\text { Increment }\end{array}$ \\
\hline \multirow{3}{*}{ X } & Group A & $1 / 10$ & $10 \%$ & $4 / 10$ & $40 \%$ & 3 & $30 \%$ \\
\cline { 2 - 8 } & Group B & $4 / 10$ & $40 \%$ & $7 / 10$ & $70 \%$ & 3 & $30 \%$ \\
\cline { 2 - 8 } & Group C & $6 / 10$ & $60 \%$ & $9 / 10$ & $90 \%$ & 3 & $30 \%$ \\
\hline \multirow{3}{*}{ Y } & Group A & $1 / 10$ & $10 \%$ & $4 / 10$ & $40 \%$ & 3 & $30 \%$ \\
\cline { 2 - 8 } & Group B & $3 / 10$ & $30 \%$ & $6 / 10$ & $60 \%$ & 3 & $30 \%$ \\
\cline { 2 - 8 } & Group C & $5 / 10$ & $50 \%$ & $9 / 10$ & $90 \%$ & 4 & $40 \%$ \\
\hline \multirow{3}{*}{$Z$} & Group A & $2 / 10$ & $20 \%$ & $5 / 10$ & $50 \%$ & 3 & $30 \%$ \\
\cline { 2 - 8 } & Group B & $4 / 10$ & $40 \%$ & $8 / 10$ & $80 \%$ & 4 & $40 \%$ \\
\cline { 2 - 7 } & Group C & $7 / 10$ & $70 \%$ & $10 / 10$ & $100 \%$ & 3 & $30 \%$ \\
\hline
\end{tabular}

Table 1: Result of the Social Expression Skills Pre-Test and Post-Test

Table 1 presented the average scores of the three schools in both of the pre-test and post-test. The participants in Group A for each school were consisted of the low achievers, while participants in Group B were the intermediate learners and the participants in Group C were the advanced learners. After being drilled and exposed to the Voice Changer app, all participants were able to score better in the post test with the increment of at least 3 marks. The pupils succeeded in recognizing the purpose of each dialogue by relating it to the audio clips before answering. Through the usage of traditional ways, the mean percentage of pupils who manage to understand the correct social expressions is only $36.7 \%$. Therefore, by implementing the Voice Changer app, the percentage has increased by $32.7 \%$ to $68.9 \%$. From the mean marks obtained, we could summarize that the implementation of the Voice Changer app was effective in helping the students to enhance pupils' understanding on social expression skills. 
INTERNATIONAL JOURNAL OF ACADEMIC RESEARCH IN BUSINESS AND SOCIAL SCIENCES

Vol. 9, No. 1, Jan, 2019, E-ISSN: 2222-6990 @ 2019 HRMARS

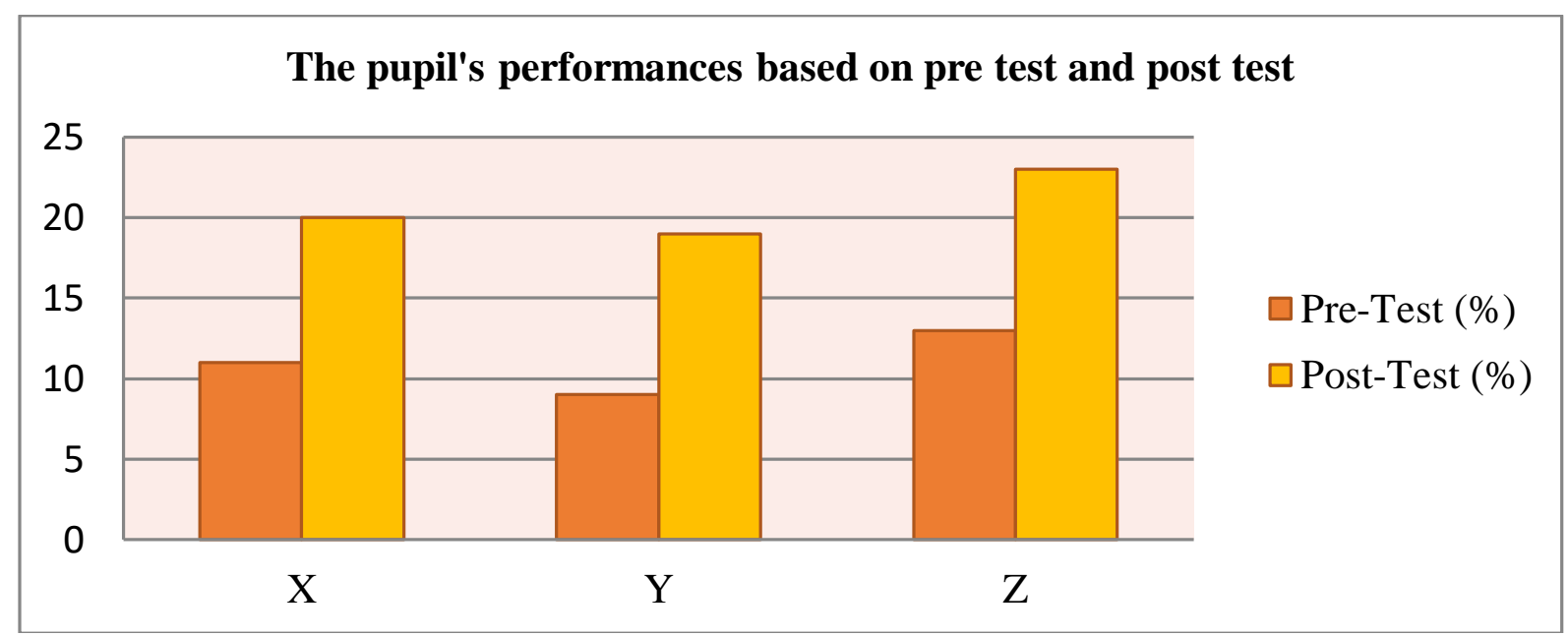

Diagram 1: The Pupil's Performance Based on Pre-Test and Post-Test

Additionally, Diagram 1 showed that in the social expression pre-test, the participants from School $X$ had collectively scored 11 marks, participants from School Y recorded 9 marks, while participants from School Z managed to get 13 marks. After the implementation of the Voice Changer app in the social expression lessons, the overall marks between the schools were seemingly higher in the posttest; participants from School $X$ had succeeded in obtaining the average of 20 marks, participants from School $Y$ had increased their marks to the average of 19 in total, and also likewise for the participants in School Z had managed to get the average marks of 23 in the post-test. This result had revealed that all participants from each school had positively attained better social expression skills after being introduced to the Voice Changer app.

\begin{tabular}{|c|c|c|c|c|c|}
\hline \multicolumn{7}{|c|}{ Voice Changer App Satisfaction Questionnaire } \\
\hline Q & Strongly Disagree & Disagree & Undecided & Agree & Strongly Agree \\
\hline 1 & - & 5 & 5 & 28 & 22 \\
\hline 2 & - & 4 & 6 & 19 & 31 \\
\hline 3 & - & 4 & 3 & 22 & 29 \\
\hline 4 & - & 2 & - & 31 & 27 \\
\hline 5 & - & 3 & 6 & 20 & 31 \\
\hline 6 & - & 3 & - & 26 & 31 \\
\hline 7 & - & 9 & - & 23 & 28 \\
\hline 8 & 3 & 4 & 3 & 28 & 22 \\
\hline 9 & - & 4 & - & 30 & 26 \\
\hline 10 & - & - & - & 20 & 40 \\
\hline
\end{tabular}

Table 2: Voice Changer Satisfaction Questionnaire

Apart from that, Table 2 showed that through the questionnaire, most students gave positive feedbacks by choosing either agree and strongly agree on the usage and benefit of Voice Changer app. In questionnaire number 8 , there were 3 pupils who opted for strongly disagree because they 
did not understand the question and considered as the weakest pupils in the class. Meanwhile, the result from questionnaire number 9 showed that almost all participants agreed to learn by using the Voice Changer app and all participants requested to use it again for the next lesson as seen from questionnaire number 10 . These positive feedbacks were also supported through the active participation showed during the lesson. The passive pupils were intrigued by the audio recordings and became interested to take part in answering the social expressions. The data indicated that the use of sound clips for each purpose of the social expression assisted the pupils to understand and applied the dialogue effectively and correctly.

\section{Discussion}

The Voice Changer App is free, works offline and convenient as it is an uncomplicated app and can be updated anytime through Google Play Store. Other than that, it is very user-friendly since the teacher and parents can use it at anytime and anywhere as long as they have the access to smartphones, tablets or laptop. It is hassle free, time saving and versatile as teachers can produce engaging and creative audio recordings at any time and for any lesson. Apart from that, the voice recordings seemed to be better at capturing learners' attention than the typical teacher's voice as they were fascinated and curious about the owner of the voice in the clips and had produced a mysterious sense of suspense (Choo \& Yunus, 2016). The most important thing is the teacher need not to worry about making sure the tone and intonation will vary every lesson as it is recorded and is just one push away whenever it is needed.

Apart from that, the Voice Changer app benefits the society by inculcating the skills of being an effective listener and user to the correct social expressions. The teacher can reduce their workloads in preparing their teaching aids as it allows them to record and play the recordings at any times for unlimited times. It also promotes collaborative learning between the pupils, teachers and parents since the teachers can share the recordings with the parents and therefore allow the pupils to learn it at home with them.

\section{Conclusion and Recommendations}

The Voice Changer app has been found to be effective in assisting the pupils to learn the appropriate way of responding to social expressions in their daily lives as well as motivating them to learn English as the Second Language. Teaching social expressions by using variety of voice characters has provided them with authentic, interesting and up-to-date learning technique. The result also disclosed that the use of ICT, in this case, smartphone, is successful in drawing the pupils' attention (Yunus, Nordin, Salehi, Choo \& Embi, 2013). Thus, teachers must ensure that the voice is recorded with clear and correct pronunciation, tone and intonation.

The authors would like to recommend that the British Council Malaysia provides the teachers with samples of the voice recordings by native English speakers on social expressions with the right articulation, intonation and stress so that the teachers can use them as guidance when producing their own recordings. It would be best if the sample recordings fit in the Malaysian context in order for the pupils to easily relate to the situations. Furthermore, the pupils can also repeat the voice 
INTERNATIONAL JOURNAL OF ACADEMIC RESEARCH IN BUSINESS AND SOCIAL SCIENCES

Vol. 9, No. 1, Jan, 2019, E-ISSN: 2222-6990 (C) 2019 HRMARS

recordings by the native speakers so that they can practice the language with the correct pronunciation and intonation at any time and places.

Future study on this topic may focus on understanding how the pupils' first language (L1) affects their social expressions skills in English. As they are ESL students, they may have difficulty in listening critically in English and use direct translations from L1 when organizing their sentence structures.

\section{Acknowledgement}

There is no conflict of interest to disclose. This article has been completed with no external funding. The authors gratefully acknowledged Universiti Kebangsaan Malaysia for providing the platform to conduct this research. Also, the authors would want to express profound gratitude to their team members and family for their countless support throughout the process of completing this research.

\section{References}

Asemota, H. E. (2015). Nature, Importance and Practice of Listening Skill. European Centre for Research Training and Development UK, 3(7), 27-33.

Astro Tutor TV. (2015). Tips Social Expression Questions. Retrieved from https://www.tutortv.com.my/upsr/files/tips/topic-51.pdf

Bandura, A. (1977). Social learning theory. Englewood Cliffs, NJ: Prentice Hall.

Choo, S. S., \& Yunus, M. M. (2016). Audio Clips In Developing Listening Comprehension Skills In Malaysian Primary EsI Classrooms. Proceedings of the ICECRS, 1(1). doi:10.21070/picecrs.v1i1.511

Chuah, K. H. (2012). Making Sense of Teacher Participants' Graphic Organizers in a Second Order Action Research: Reflection of the Voice of an Action Researcher. US-China Education Review B 5 (2012) 499-509.

Darmi, R \& Albian, P (2013). English Language In the Malaysian Education System: Its existence and Implications. Malaysian Postgraduate Conference 2013-35;175-183

Harrowoth, G.L. (1966). Listening: A fact of oral Language. Elementary English 43, pp. 856-864.

Ministry of Education. (2013). Preliminary Report: Malaysia Education Blueprint 2013-2025.. Retrieved from https://www.moe.gov.my/index.php/en/dasar/pelan-pembangunan-pendidikanmalaysia-2013-2025

Muniandy, J., (2012) Teaching and learning constructive listening skills: A study among EFL learners. e-BANGI: Journal of Social Sciences and Humanities, 7 (1). pp. 165-176. ISSN 1823-884x 
INTERNATIONAL JOURNAL OF ACADEMIC RESEARCH IN BUSINESS AND SOCIAL SCIENCES

Vol. 9, No. 1, Jan, 2019, E-ISSN: 2222-6990 (C) 2019 HRMARS

Skinner, K. L., Hyde, S. J., McPherson, K. B., \& Simpson, M. D. (2016). Improving students' interpersonal skills through experiential small group learning. Journal of Learning Design, 9(1), 21.

Tigarajan, D., Yunus, M. M., \& Aziz, A. A. (2016). What good language learners do to learn English language. Proceeding - Kuala Lumpur International Communication, Education, Language and Social Sciences 5.

Vygotsky, L. S. (1978). Mind in society: The development of higher psychological processes. Cambridge, MA: Harvard University Press.

Weger, H., Castle Bell, G., Minei, E. M., \& Robinson, M. C. (2014). The Relative Effectiveness of Active Listening in Initial Interactions. International Journal of Listening, 28(1), 13-31.

doi:10.1080/10904018.2013.813234

West, D. M. (2013). Digital schools: How technology can transform education. Washington, DC: Brookings Institution Press.

Wolvin, A. D., \& Coakley, C. G. (1994). Listening Competency. International Listening Association. Journal, 8(1), 148-160. doi:10.1080/10904018.1994.10499135

Yunus, M. M., Nordin, N., Salehi, H., Choo, H. S., \& Embi, M. A. (2013). Pros and Cons of Using ICT in Teaching ESL Reading and Writing. International Education Studies, 6(7). doi:10.5539/ies.v6n7p119 